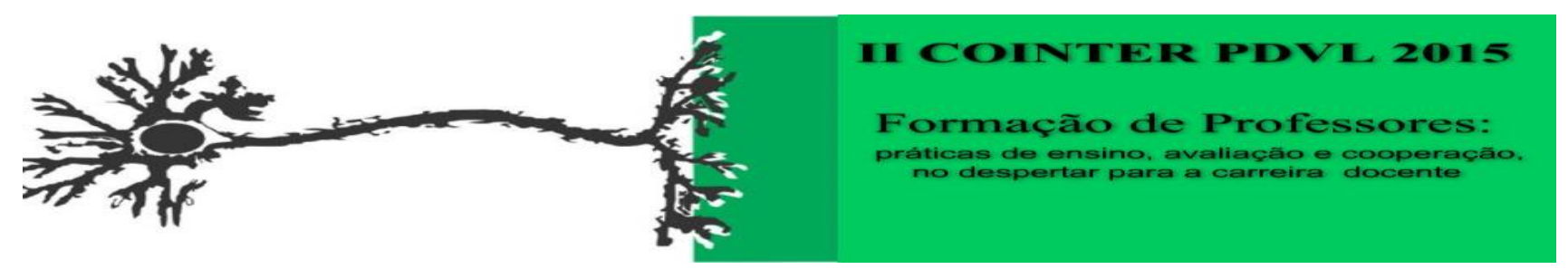

\title{
APRENDIZAGEM DE FÍSICA A PARTIR DE UM ESPETÁCULO CIRCENSE
}

\begin{abstract}
Apresentação: Relato de Experiência
Jan Pierre Modesto Alves ${ }^{1}$; Indira Alves dos Santos ${ }^{2}$; Albertina Marília Alves Guedes ${ }^{3}$

\section{Introdução}

O processo de ensino e aprendizagem dos conhecimentos básicos na área de Física, na maioria das vezes, é abordado em sala de aula restringindo-se apenas à resolução de problemas e exercícios na lousa, o que por sua vez, resulta em uma aprendizagem descontextualizada e sem motivação (GOMES, 2007). No entanto, a presença de atividades práticas na ação pedagógica do professor é possível despertar o interesse e motivação do aluno pela disciplina de Física, proporcionando ao estudante oportunidades de ampliar o seu conhecimento mediante a discussão e reflexão sobre os conteúdos estudando em sala de aula (BORTOLETO, 2008). Além disso, Bortoleto (2008) apresenta que uma excelente oportunidade para o professor desenvolver atividades pedagógicas que desperte o interesse e motivação dos alunos em aprender é inserir na metodologia de ensino atividades relacionada à arte, tais como: teatro, música, circo, pintura, dentre outros.
\end{abstract}

\section{Relato da Experiência}

Essa experiência refere-se à realização de uma atividade pedagógica sobre os conteúdos Físicos de "reflexão e refração da luz" a partir da análise de um espetáculo circense intitulado "Monga: A Mulher que se Transforma em Macaco" durante a disciplina de Oficina de Física II oferecida no Curso de Licenciatura em Física do IF Sertão PE. Essa atividade foi vivenciada com 10 alunos no Projeto de Apoio Social Vida Nova com faixa etária de 7 a 12 anos. O problema que despertou o interesse dos pesquisadores para a realização desta atividade: É possível despertar o interesse e motivação de estudantes com faixa etário de 7 a 12 anos para a aprendizagem de conteúdos de Física sobre "refração" a partir da análise de um espetáculo circense?

Para o desenvolvimento desta atividade, inicialmente, foi socializado com os alunos o artigo "Uma atividade prática motivadora para o aprendizado dos conceitos de reflexão e refração da luz" (GOMES, 2007). Posteriormente, foi confeccionado, em escala reduzida e com o uso de vidro, madeira, lâmpadas e dimmers, uma montagem do espetáculo "Monga - A mulher que se Transforma em Macaco". Neste momento, foi possível revelar aos alunos, a partir dos conceitos

\footnotetext{
${ }^{1}$ Estudante do Curso de Licenciatura em Física. IF Sertão PE, Campus Petrolina. E-mail: pierremodesto@hotmail.com

${ }^{2}$ Estudante do Curso de Licenciatura em Física. IF Sertão PE, Campus Petrolina. E-mail: indira.alves.2012@hotmail.com

${ }^{3}$ Professora do Curso de Licenciatura em Física. IF Sertão PE, Campus Petrolina. E-mail: albertinamarilia@hotmail.com
} 
físicos de reflexão e refração da luz, os truques das transformações dos personagens no referido espetáculo.

Cada aluno recebeu um papel ofício e um lápis para que ao final espetáculo desenhassem e/ou escrevessem todos os detalhes da cena que eles observaram. Em seguida, foi realizada uma discussão com os alunos sobre "o que viram, o que perceberam e como descreveriam a transformação". Neste momento, alguns alunos relataram que a transformação ocorria devido à presença de espelhos na caixa de madeira. Outros descreveram que a pessoa controlava a caixa de madeira fazia a mudança dos personagens. No entanto, a maioria dos alunos conseguiu identificar o vidro e a troca de luminosidade (GOMES, 2007).

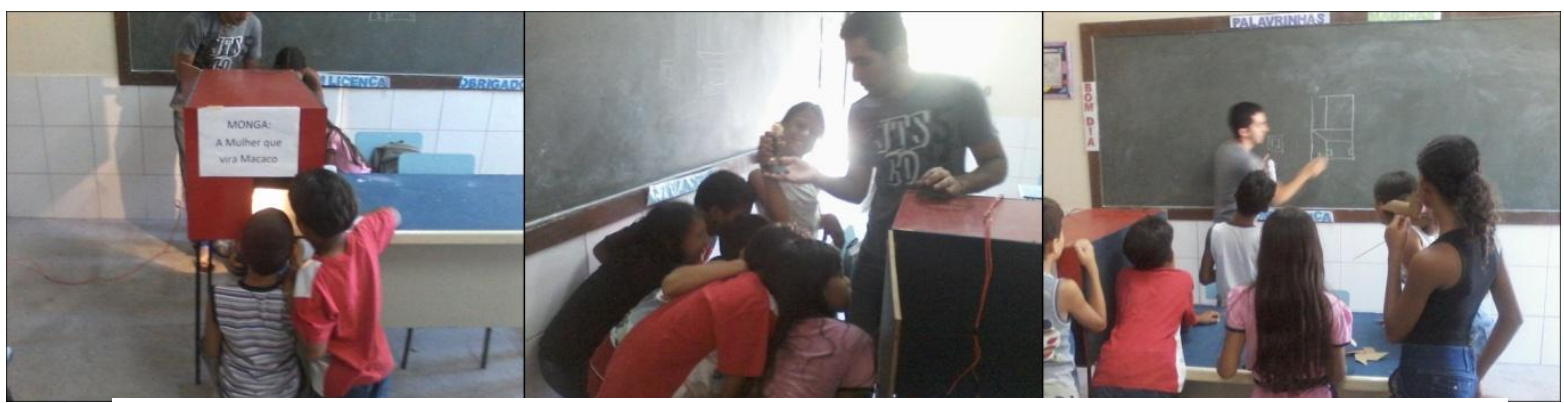

Imagem 1. Explicando os Conceitos Físicos sobre Reflexão e Refração da Luz. Fonte: Própria

Verificou-se também que os alunos ficaram encantados com a realização do espetáculo e, até mesmo, ousaram dar explicações sobre o que aconteceu apesar de não terem ainda o conhecimento e, tampouco, saberem utilizar os nomes científicos que explicam os referidos fenômenos - reflexão e refração. Todavia, após as explicações dos estudantes do Curso de Licenciatura em Física os alunos puderam compreender o que havia acontecido.

\section{Considerações Finais}

A partir desta experiência verificamos que mediante o uso da arte é possível que alunos do Ensino Fundamental com faixa entre 7 a 12 anos compreendam e aprendam conteúdos básicos da Física relacionados à reflexão e refração da luz. Verificamos também que a partir da realização de atividades pedagógicas que envolvem a arte, tais como o utilizado neste Relato de Experiência, um Espetáculo Circense, é possível despertar o interesse e a motivação desses alunos em aprender conteúdos básicos da Física.

\section{Referências}

BORTOLETO, M. A. C. Introdução à pedagogia das atividades circenses. Jundiaí: Fontoura. 2008. GOMES, L. C. Uma atividade prática motivadora para o aprendizado dos conceitos de reflexão e refração da luz. Revista Ciência e Ensino, vol. 2, n. 1, dez 2007. 